\title{
PELATIHAN BAHASA PRANCIS PRAKTIS PADA KARYAWAN FRESHMART EXPRESS TELING MANADO
}

\author{
Grace Shirley Luntungan \\ Fakultas Bahasa dan Seni, Universitas Negeri Manado
}

\begin{abstract}
Abstrak
Kapasitas berkomunikasi lisan dalam bahasa Prancis berarti dapat berkomunikasi dalam hubungan yang lazim dari kehidupan professional. Para pelaku pariwisata dalam hal ini termasuk juga Karyawan Freshmart Express Teling Manado memang perlu memiliki kapasitas seperti ini dalam melayani wisatawan Prancis secara benar agar tidak terjadi kesalahpahaman dalam berkomunikasi ketika mereka datang berkunjung. Kebutuhan ini terpenuhi dengan adanya pelatihan bahasa Prancis tentang penyambutan dalam pelayanan wisatawan, pemberian informasi arah jalan dan situasi tempat, pemberian informasi tentang barang jualan, produksi turistik lokal, informasi harga, serta penggunaan waktu.

Kata Kunci: wisatawan, Bahasa Perancis, karyawan.
\end{abstract}

\section{PENDAHULUAN}

\section{Analisis Situasi}

Kota Manado semakin dikenal di mancanegara karena keindahan alam, keramahtamahan penduduknya, kuliner yang beraneka ragam, objek wisata dengan berbagai fasilitas pendukung, sehingga menghipnotis banyak wisatawan untuk datang berkunjung menikmati kekayaan alam ini. Pemerintah kota pun terus berupaya untuk lebih mempercantik Kota Manado dengan berbagai hal, baik infrastruktur, maupun bidang jasa. Di bidang jasa diupayakan adanya kesiapan dari para pemberi layanan tersebut, salah satunya dalam hal bahasa sebagai alat komunikasi.

Freshmart Express Teling Manado merupakan toko serba ada, dan toko kelontong yang letaknya di Jalan 14 Februari, Teling, Manado, Sulawesi Utara, yang banyak dikunjungi pembeli lokal maupun internasional. Toserba ini letaknya memang tidak jauh juga dari kompleks perkantoran pemerintah, rumah sakit, sekolah, biro perjalanan, sehingga sangat memungkinkan wisatawan mancanegara untuk datang membeli berbagai keperluan di tempat ini. Tidak ketinggalan juga wisatawan Prancis.

Dengan demikian para karyawan toko serba ada ini perlu dibekali dengan pengetahuan berbahasa Prancis misalnya memberi salam, menanyakan identitas tamunya, memberi informasi atau sebaliknya, serta kiat-kiat praktis dalam melayani wisatawan berbahasa Prancis, sehingga mereka dapat memahami apa yang diinginkan atau ditanyakan oleh wisatawan Prancis kepada mereka, baik menyangkut harga, letak barang, arah jalan, dan lain-lain yang berhubungan dengan fasilitas tokoh.

Jadi tujuan dibekalinya para karyawan ini dengan bahasa Prancis Praktis yaitu agar mereka mampu menerapkannya dalam situasi yang nyata karena 
berdasarkan pengamatan mereka hanya mampu berkomunikasi dalam bahasa Inggris. Kapasitas berkomunikasi lisan dalam bahasa Prancis berarti dapat berkomunikasi dalam hubungan yang lazim dari kehidupan professional. Para karyawan toko ini juga termasuk pelaku pariwisata memang perlu memiliki kapasitas seperti ini dalam melayani wisatawan Prancis secara benar agar tidak terjadi kesalahpahaman dalam berkomunikasi ketika mereka datang berbelanja.

Berdasarkan situasi tersebut di atas, maka UNIMA melalui Lembaga Pengabdian Kepada Masyarakat melakukan kegiatan pelatihan bahasa Prancis praktis pada karyawan Freshmart Express Teling Manado dalam melayani wisatawan Prancis yang datang berkunjung.

\section{Identifikasi dan Perumusan Masalah}

Berdasarkan analisis situasi yang dilakukan, maka permasalahan yang ada yakni minimnya pengetahuan bahasa Prancis yang dimiliki oleh pelaku pariwisata yang dalam hal ini karyawan Freshmart Express Teling Manado. Adapun masalah yang perlu diatasi sehubungan dengan kegiatan yang dilaksanakan ini dapat dirumuskan sebagai berikut :

1. Minimnya pengetahuan bahasa Prancis pada karyawan Freshmart Express Teling Manado dalam berkomunikasi pada kontak awal dengan para wisatawan berbahasa Prancis;
2. Minimnya pengetahuan bahasa Prancis pada karyawan Freshmart Express Teling Manado dalam memberi informasi arah jalan dan situasi tempat;

3. Minimnya pengetahuan bahasa Prancis karyawan Freshmart Express Teling Manado dalam memberi informasi tentang barang jualan;

4. Minimnya pengetahuan bahasa Prancis pada karyawan Freshmart Express Teling Manado dalam memberi informasi tentang produksi turistik lokal;

5. Minimnya pengetahuan bahasa Prancis pada karyawan Freshmart Express Teling Manado dalam memberi informasi tentang harga; dan

6. Minimnya pengetahuan bahasa Prancis pada karyawan Freshmart Express Teling Manado dalam penggunaan waktu.

\section{Tujuan dan Manfaat Kegiatan}

Tujuan pelaksanaan kegiatan ini yaitu membekali para karyawan Freshmart Express Teling Manado dengan pengetahuan bahasa Prancis dalam melayani wisatawan Prancis. Manfaat kegiatan ini yaitu :

1. Karyawan Freshmart Express Teling Manado memiliki kemampuan berkomunikasi pada kontak awal dengan para wisatawan berbahasa Prancis;

2. Karyawan Freshmart Express Teling Manado memiliki kemampuan memberi 
informasi arah jalan dan situasi tempat dalam bahasa Prancis;

3. Karyawan Freshmart Express Teling Manado memiliki kemampuan memberi informasi tentang barang jualan dalam bahasa Prancis;

4. Karyawan Freshmart Express Teling Manado memiliki kemampuan memberi informasi tentang produksi turistik lokal dalam bahasa Prancis;

5. Karyawan Freshmart Express Teling Manado memiliki kemampuan dalam memberi informasi tentang harga barang jualan dalam bahasa Prancis; dan

6. Karyawan Freshmart Express Teling Manado memiliki kemampuan dalam menggunakan waktu dalam bahasa Prancis.

\section{Kerangka Pemecahan Masalah}

Pemecahan masalah ditempuh dengan cara memberikan pelatihan bahasa Prancis tentang penyambutan dalam pelayanan wisatawan, pemberian informasi arah jalan dan situasi tempat, pemberian informasi tentang barang jualan, produksi turistik lokal, informasi harga, perbandingan kualitas dan kuantitas, serta penggunaan waktu.

Pendekatan yang digunakan dalam kegiatan pelatihan ini adalah approche communicative dengan metode langsung yakni : mendengar rekaman, ceramah, tanya jawab dan bermain peran dengan menggunakan media dan bahan pelatihan berupa buku sumber, LCD Projector, dan komputer.

\section{METODE PELAKSANAAN}

Pelaksanaan Kegiatan

\section{Persiapan}
a. Penyusunan proposal
b. Penyiapan lokasi
c. Penyiapan materi dan media

\section{Pelaksanaan}

a. Mengadakan pertemuan dengan Store Manager Freshmart Express Teling Manado.

b. Melaksanakan Pelatihan dengan langkah-langkah sebagai berikut:

1. Inisiasi/pengantar: Mendengarkan cakapan rekaman untuk mengidentifikasi kata/ kalimat/ungkapan model, dan mendengarkan kembali cakapan rekaman untuk menemukan kata/kalimat/ungkapan model.

2. Fermentasi/penyerapan: Meniru/mengulagi rekaman cakapan model secara bersamasama, bergilir, atau sendiri.

3. Aplikasi/simulasi/interpretasi cakapan model.

\section{Materi Kegiatan}

I. Accueil merupakan kegiatan penerimaan atau penyambutan kepada wisatawan yang berbahasa Prancis yang datang di tempat perbelanjaan. 
II. Comment localiser yaitu bagaimana menunjukkan arah/tujuan.

III. Faire des courses yaitu berbelanja yang disertai berbagai jenis barang/ makanan jualan dalam super market atau super store.

IV. Vente d'un produit touristique local yaitu bagaimana menjual produksi turistik lokal.

V. Demander et donner l'information yaitu bagaimana bertanya dan memberi informasi dalam hal ini harga barang jualan.

VI. L'emploi du temps yaitu penggunaan waktu dalam hal ini jam buka toko maupun jam tutup toko maupun cara memberi informasi tentang waktu lainnya.

\section{Keterkaitan dan Khalayak Sasaran}

Kegiatan ini erat kaitannya dengan dicanangkannya Manado sebagai Kota Pariwisata Dunia. Sebagai kota pariwisata dunia perlu mempersiapkan para pelaku pariwisata dalam hal ini Karyawan Freshmart Express Teling Manado, yang harus siap pakai dalam menyambut wisatawan dunia khususnya wisatawan Prancis.

Program Lembaga Pengabdian kepada Masyarakat Unima ini turut juga membantu program pemerintah daerah dalam memajukan sektor pariwisata untuk bisa menarik banyak wisatawan asing khususnya wisatawan Prancis untuk datang di Sulawesi Utara khususnya kota Manado. 38
Khalayak sasaran adalah Karyawan Freshmart Express Teling Manado.

\section{HASIL DAN PEMBAHASAN}

Selesai kegiatan pelatihan, para peserta menunjukkan kepuasan dan mampu membuktikan kemampuan mereka dalam berbahasa Prancis praktis untuk melayani wisatawan Prancis yang datang di Freshmart Express Teling Manado.

Dalam evaluasi bermain peran membuktikan bahwa:

1. Karyawan Freshmart Express Teling Manado mampu berkomunikasi pada kontak awal dengan para wisatawan berbahasa Prancis;

2. Karyawan Freshmart Express Teling Manado mampu memberi informasi arah jalan dan situasi tempat dalam bahasa Prancis;

3. Karyawan Freshmart Express Teling Manado mampu memberi informasi tentang barang jualan dalam bahasa Prancis;

4. Karyawan Freshmart Express Teling Manado mampu memberi informasi tentang produksi turistik lokal dalam bahasa Prancis;

5. Karyawan Freshmart Express Teling Manado mampu memberi informasi tentang harga dalam bahasa Prancis; dan

6. Karyawan Freshmart Express Teling Manado mampu menjelaskan penggunaan waktu. 


\section{KESIMPULAN DAN SARAN}

\section{Kesimpulan}

1. Pelaksanaan pelatihan ini memberi manfaat yang sangat besar bagi Karyawan Freshmart Express Teling Manado yang sebelumnya tidak mengenal bahasa Prancis kini mampu menggunakan bahasa Prancis praktis dalam melayani wisatawan Prancis.

2. Penguasaan bahasa Prancis praktis dalam melayani wisatawan Prancis yang datang di Freshmart Express Teling Manado turut menunjang pertumbuhan kepariwisataan di kota Manado.

\section{Saran}

1. Pelaksanan pelatihan seperti ini perlu dilaksanakan juga secara berkelanjutan di Pusat-pusat Perbelanjaan yang ada di kota Manado.
2. Dinas Pariwisata Kota Manado hendaknya mengalokasikan dana untuk pelaksanaan kegiatan pelatihan seperti ini dalam meningkatkan kepariwisataan yang ada di kota Manado.

\section{KEPUSTAKAAN}

Berthet, A., et al. 2006. Alter Ego 1: Livre + Guide. Paris : Hachette.

Calmy, Anne-Marie. 2004. Le Français du Tourisme. Paris : Hachette

Corbeau, S., et al. 2004. Tourisme.com. : Livre + Guide. Paris : CLE.

Direction Générale du Tourisme. 1994. Destination Indonesia. Jakarta.

Kusumastuti, Elly, Emy Dwi Lestari. 2012. Bahasa Prancis Sehari-Hari. Jakarta : Kesaint Blanc. 
Jurnal ABDIMAS, Vol. 9, No. 1, Juni 2016 ISSN: 1979-0953 